\title{
Social Physique Anxiety Levels and Influential Factors in Women Who Have Aesthetic Surgery
}

\author{
Estetik Cerrahi Girişim Yaptıran Kadınlarda \\ Sosyal Fizik Kaygı Düzeyi ve Etkileyen Faktörler
}

Yeșim AKSOY DERYA, ${ }^{a}$ Sermin TIMUR TAȘHAN, ${ }^{b}$ Mesude DUMAN, ${ }^{\circ}$ Gülçin NACAR

Departments of aMidwifery,

bNursing,

İnönü University

Faculty of Health Sciences,

Malatya

'Department of Nursing,

Dicle University School of Health,

Diyarbakır

Geliş Tarihi/Received: 27.09 .2017

Kabul Tarihi/Accepted: 30.11 .2017

Yazışma Adresi/Correspondence: Gülçin NACAR

İnönü University

Faculty of Health Sciences,

Department of Nursing, Malatya,

TURKEY/TÜRKIYE

gulcin.nacar@inonu.edu.tr

\begin{abstract}
Objective: This study aimed to investigate social physique anxiety levels and influential factors in women who have aesthetic surgery. Material and Methods: The study sample included 289 women who underwent aesthetic surgery. Results: The average period of time that women had considered aesthetic surgery was $38.91 \pm 3.73 /$ months. The first trait that participants hoped to gain with aesthetic surgery was "being more relaxed and confident" (69.2\%). The women who learned about the aesthetic surgery they had from the media (e.g. TV, newspapers), and said that the people around them "judged/condemned" them for having aesthetic surgery, obtained higher total mean scores on the "Social Physique Anxiety Scale" than the other women $(\mathrm{p}<.05)$. Conclusion: The study also found that the waiting period for the aesthetic surgery was long, the women were mainly affected by their social environment and the media, and those who had negative feedback from their social environment had higher social physique anxiety. It is recommended to investigate aesthetic surgical operations in large sample groups including frequent genital aesthetic surgery such as labioplasty and vaginoplasty.
\end{abstract}

Keywords: Aesthetic; aesthetic surgery; anxiety; labiaplasty; vaginoplasty; women

ÖZET Amaç: Bu araştırma ile estetik cerrahi girişim yaptıran kadınlardaki sosyal fizik kaygı düzeyi ve etkileyen faktörleri belirlemek amaçlanmıştır. Gereç ve Yöntemler: Araştırmanın örneklemini estetik cerrahi girişim yaptıran 289 kadın oluşturmuştur. Bulgular: Estetik cerrahi girişim için düşünülen süre ortalama $38.91 \pm 3.73$ /ay ve günde izlenen ortalama TV süresi $2.39 \pm 1.59 /$ saattir. Estetik cerrahi girişim ile kazanılması beklenen özelliklerin başında \%69.2 ile "daha rahat ve kendine güvenen" seçeneği yer almaktadır. Yapılan estetik cerrahi girişim hakkında bilgi edinme kaynağının "medya (TV, gazete vb)" olduğunu belirten ve yapılan girişim nedeni ile sosyal çevreden "yargıladılar/kınadılar" tepkisi alan katılımcıların Sosyal Fizik Kaygı Envanteri toplam puan ortalamasının diğer katılımcılara oranla daha yüksek olduğu belirlenmiştir $(\mathrm{p}<0.05)$. Sonuç: Estetik cerrahi girişim için beklenilen sürenin uzun olduğu, katılımcıların daha çok sosyal çevre ve medyadan etkilendiği ve sosyal çevreden olumsuz geri bildirim alan kişilerin sosyal fizik kaygılarının daha yüksek olduğu görülmektedir. Labiaplasti ve vajinoplasti gibi sık yapılan genital estetik cerrahiyi de içeren geniş örneklem gruplarında estetik cerrahi operasyonların araştırılması önerilmektedir.

Anahtar Kelimeler: Anksiyete; estetik; estetik cerrahi girişim; kadın; labiaplasti; vajinoplasti

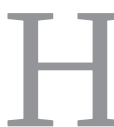
uman beings want to be perceived positively by others. This general tendency causes people to perceive their own bodies in a positive or negative way. However, some individuals are more anxious about the way their bodies are perceived by other people. ${ }^{1}$ In the relevant literature, the worry and nervousness that people feel when their physical 
appearance is being evaluated by others is described as Social Physique Anxiety (SPA). ${ }^{1,2}$ With this cause of anxiety, people resort to many avenues to shape their bodies, to be more elegant, more muscular or to look better, and this increases the demand for different aesthetic types. ${ }^{3}$

In accordance with the rapid increase in the consumption of beauty products, including aesthetic products and anti-aging creams, the elective transformation of the body through surgical interventions was included in health care behaviors, and it has become another form of personal care. ${ }^{4}$ This individual care approach has also led to a logarithmic increase in the rate of aesthetic surgery over the years. The American Society of Plastic Surgeons states that the number of aesthetic interventions in 2016 increased by 3\% compared to 2015, reaching 17.1 million interventions, 1.7 million of which were surgical operations. ${ }^{5}$ Turkey is the thirteenth highest ranked country in terms of the number of aesthetic interventions performed annually. The International Society of Aesthetic Plastic Surgery (ISAPS) stated that 305,820 aesthetic interventions were performed in Turkey in 2016, 1,200 of which included surgical operations. ${ }^{6}$

Usually, the ideal female figure is slim, without any excess body fat, and the ideal male figure is large and muscular. ${ }^{1}$ The mass media use images of attractive, thin female figures and muscular male figures in their publications and broadcasts, which makes society want to look like these figures. ${ }^{1,7}$ Moreover, in addition to physical characteristics such as structural deformities in the body, it is stated that aesthetic surgery decisions are affected by various psychological and sociocultural factors including education, culture, body image, self-respect, being a subject of ridicule and social physique anxiety levels. ${ }^{9-13}$ However, as the media do not take early period and future dangers in aesthetic surgery procedures seriously and produce advertisements based on unrealistic beauty standards, individuals gain incorrect and unrealistic expectations about aesthetic surgery. ${ }^{3}$ For this reason, it is very important for the planning of future health care services that health professionals consider the rapid increase in the aesthetic surgery rates and make an accurate diagnosis of the underlying reasons for aesthetic surgery. ${ }^{9,10}$

This study aimed to investigate social physique anxiety levels and influential factors in individuals who have aesthetic surgery.

\section{MATERIAL AND METHODS}

This is a descriptive and cross-sectional study. The study was conducted in the Plastic Surgery Outpatient Clinic of Dicle University Medical Faculty, in eastern Turkey. The sample of the study included those who came to the Outpatient Clinic between 16 December 2013 and 1 January 2015, subsequent to an aesthetic surgery.

The 289 women in the sample were selected from the study universe using the improbable random sampling method. The criteria to be included in the study sample were: having had an elective aesthetic surgery; having had the surgery less than 20 days ago; and participating in the study voluntarily. Those who had post- intervention complications were not included in the study. The study data were collected from those who met the research criteria, in interviews held by the researchers over five weekdays.

The study data were collected at a special section in the outpatient clinic after their check-ups, with the purpose of having the participants respond to questions more comfortably.

\section{DATA COLLECTION}

The study data were collected using the Social Physique Anxiety Inventory (SPAS), in addition to the Participant Information Form that was created by the researchers based on the relevant literature. ${ }^{7-10,12,14-16}$

Participant information form. The Participant Information Form had 23 questions about sociodemographic characteristics and the reasons and influencing factors for aesthetic surgery (e.g. age, occupation, education level, marital status, economic condition, name of the aesthetic surgery that participant had, the period of time that the participant considered having an aesthetic surgery, the reason for having an aesthetic surgery, the reac- 
tions from their social environment towards the decision to have an aesthetic surgery, and emotional changes experienced after the aesthetic surgery). It took approximately 10 minutes to complete the Participant Information Form.

Social Physique Anxiety Scale (SPAS). The SPAS was created by Hart et al. (1989) with the purpose of determining individuals' social physique anxiety levels. It was translated into Turkish by Mülazımoğlu, Ballı and Aşçı (2006). The inventory includes 12 items and two sub-dimensions. The items are answered using a 5-point Likert type scale. The minimum score on the inventory is 12 , and the maximum score is 60 . Individuals' level of anxiety about their physical appearance increases in direct proportion with their score on SPAS. There are two sub-dimensions in SPAS which are physical appearance relaxation (PAR [being uncomfortable about own physical appearance]), and negative evaluation expectation (NEE [the expectation of getting a negative evaluation from others about own physical appearance]). The Cronbach's alfa internal consistency coefficient of the original inventory was $0.88(\mathrm{p}<.01) .{ }^{17}$ In this study, the Cronbach's alpha internal consistency coefficient of SPAS was 0.83 .

\section{STATISTICAL ANALYSIS}

The study data were evaluated using SPSS 16.00 software. The study used arithmetic means, percentage distribution, students' $t$ test, ANOVA and Cronbach's alpha coefficient to analyze the data. Multiple regression analysis was used to determine the predictive power of participants' individual characteristics on the study variables. The statistical significance level of the study was $\mathrm{p}<.05$.

\section{ETHICAL CONSIDERATIONS}

The researchers obtained the approval of the Dicle University Medical Faculty Non-invasive Clinical Research Board (Approval \# 2013/13) before conducting the study. The researchers also took the written consent of the institution where the study was conducted. The participants were informed about the study, and the voluntary participants were included in the study after being reassured that their personal information would be kept confidential and they could withdraw from the study whenever they wished.

\section{STUDY LIMITATIONS}

This study is limited to the plastic surgery outpatient clinic of a hospital in an eastern province of Turkey.

\section{RESULTS}

The average age of the participants was $29.43 \pm 7.95$ years. Overall, $60.6 \%$ of them were single and $52.2 \%$ had university degrees. Around half the participants $(51.6 \%)$ were employed and stated that their income were sufficient to afford their expenses (50.5\%). On average, the participants watched TV $2.39 \pm 1.59$ hours a day. The TV programs they watched the most were soap operas/film (45.7\%), entertainment shows (40.5), news programs (29.1\%), fashion/aesthetic programs (28\%), general culture programs (3.8\%), and health programs (2.1\%).

Table 1 presents the distribution of some variables about aesthetic surgery. Of the participants in the study, $66.8 \%$ stated that there were other individuals in their social environment who had aesthetic surgery. In addition, $30.4 \%$ were afraid of aesthetic surgery, $22.8 \%$ could not find a physician that they could trust, $17 \%$ delayed making a decision about the surgery due to their age, and $15.6 \%$ could not decide due to financial reasons. Respectively, the characteristics that participants aimed to gain through aesthetic surgery were being more relaxed and self-confident (69.2\%), being more attractive and beautiful/handsome (38.8\%), becoming more feminine (18.3\%), being more successful in family, social and professional relationships (9.7\%), and being more satisfied sexually $(8.3 \%)$. The rate of having regrets after undergoing aesthetic surgery was $12 \%$. On average, the participants considered having aesthetic surgery for $38.91 \pm 3.73$ months, and spent $946.23 \pm 593.43$ USD for their operation.

Table 2 presents the comparison of participant characteristics related to aesthetic surgery, with 


\begin{tabular}{|c|c|c|}
\hline Variables & $\mathrm{n}$ & $\%$ \\
\hline \multicolumn{3}{|c|}{ Presence of any individuals in the social environment who had aesthetic surgery } \\
\hline Yes & 193 & 66.8 \\
\hline No & 96 & 33.2 \\
\hline \multicolumn{3}{|l|}{ Reason for postponing aesthetic surgery until now } \\
\hline Being afraid of aesthetic surgery & 88 & 30.4 \\
\hline Failing to find a physician to trust & 66 & 22.8 \\
\hline Postponing due to age & 49 & 17.0 \\
\hline Financial reasons & 45 & 15.6 \\
\hline Failing to get the approval of family & 23 & 8.0 \\
\hline Religious beliefs & 11 & 3.8 \\
\hline Failing to get the approval of spouse/partner & 7 & 2.4 \\
\hline \multicolumn{3}{|l|}{ \& Feelings after the aesthetic surgery } \\
\hline More relaxed and self-confident & 200 & 69.2 \\
\hline More attractive and beautiful & 112 & 38.8 \\
\hline More feminine & 53 & 18.3 \\
\hline More successful at family, social and professional relationships & 28 & 9.7 \\
\hline More satisfied sexually & 24 & 8.3 \\
\hline \multicolumn{3}{|l|}{ Having regrets after the aesthetic surgery } \\
\hline Yes & 35 & 12.0 \\
\hline No & 291 & 88.0 \\
\hline The period of time spent considering the aesthetic surgery (month) & $38.91 \pm 3$ & \\
\hline The amount of money spent for aesthetic surgery (USD) & $946.23 \pm 59$ & \\
\hline
\end{tabular}

\&Includes multiple statements.

their sub-dimension and total mean scores on SPAS. An analysis of the aesthetic surgery undergone by the participants showed that the PAR mean score of the participants who had anti-aging operation was $17.66 \pm 7.06(\mathrm{p}<.05)$, and the NEE mean score of the participants who had liposuction operations was $24.05 \pm 6.01(\mathrm{p}<.05)$. Thus, these two groups of participants had the highest levels of anxiety. It was also found that the SPAS mean score of the participants who had anti-aging operation $(40.83 \pm 15.75)$ was higher than other participants who had aesthetic surgery, and the difference between them was statistically significant $(\mathrm{p}<.05)$.

An analysis of the reasons for having aesthetic surgery indicated that the mean score of the participants who had decided to have operations because of the negative evaluations they got from others $(21.42 \pm 6.57)$ was higher than the other participants, and the difference between them was statistically significant $(\mathrm{p}<.05)$. The SPAS mean score of the participants who learned about aesthetic surgery from the media (e.g. TV, newspapers) was $35.24 \pm 8.46$, which indicates the highest anxiety level, and the difference between them and the other participants was statistically significant $(\mathrm{p}<$ $.05)$.

The total SPAS mean score of the participants stating that they were judged or condemned by those in their environment because of having an aesthetic surgery was $37.26 \pm 10.47$, which indicated the highest anxiety level, and the difference between them and the other participants was statistically significant $(\mathrm{p}<.05)$.

The study conducted a regression analysis to determine the effect of participants' demographic characteristics on the total score of SPAS. The results of the regression analysis are presented in Table 3. The study found that total score of SPAS were no affected by age, marital status, employment status, education level and income level ( $\mathrm{p}>.05)$. 
TABLE 2: The comparison of participant characteristics related to aesthetic surgery, with their sub-dimension and total mean scores on SPAS $(n=289)$.

\begin{tabular}{|c|c|c|c|c|c|}
\hline Survey item & $\mathrm{n}$ & $\%$ & PAR & NEE & Total \\
\hline \multicolumn{6}{|l|}{ Aesthetic surgery applied } \\
\hline Rhinoplasty (nose surgery) & 208 & 72.0 & $12.55 \pm 3.79$ & $18.79 \pm 5.92$ & $31.36 \pm 8.51$ \\
\hline Breast reduction & 24 & 8.3 & $13.08 \pm 5.64$ & $18.50 \pm 8.01$ & $31.58 \pm 13.00$ \\
\hline Prominent ear surgery & 20 & 6.9 & $13.60 \pm 3.99$ & $21.50 \pm 6.17$ & $35.10 \pm 9.56$ \\
\hline Liposuction & 17 & 5.9 & $13.70 \pm 3.88$ & $24.05 \pm 6.01$ & $37.76 \pm 8.21$ \\
\hline Breast augmentation & 12 & 4.2 & $14.83 \pm 3.66$ & $23.00 \pm 4.06$ & $37.83 \pm 6.47$ \\
\hline \multirow[t]{2}{*}{ Anti-aging operations } & 8 & 2.7 & $17.66 \pm 7.06$ & $22.16 \pm 9.02$ & $40.83 \pm 15.75$ \\
\hline & $F ; p$ & & $2.367 ; 0.025^{\star}$ & $2.367 ; 0.025^{\star}$ & $2.367 ; 0.025^{\star}$ \\
\hline \multicolumn{6}{|l|}{ Reason for undergoing an aesthetic surgery } \\
\hline Obtaining the look I desire & 205 & 70.9 & $13.14 \pm 4.14$ & $19.59 \pm 6.37$ & $32.74 \pm 9.42$ \\
\hline Negative comments I get from other people & 28 & 9.7 & $12.25 \pm 4.33$ & $21.42 \pm 6.57$ & $33.67 \pm 9.68$ \\
\hline The desire to resemble someone else (e.g. a celebrity, a friend of family) & 28 & 9.7 & $11.71 \pm 4.64$ & $16.82 \pm 6.26$ & $28.53 \pm 9.72$ \\
\hline \multirow[t]{2}{*}{ On the wish of spouse/ partner } & 28 & 9.7 & $13.50 \pm 2.98$ & $19.96 \pm 4.71$ & $33.46 \pm 7.26$ \\
\hline & $F ; p$ & & $1.430 ; .234$ & $2.668 ; .048^{*}$ & $1.993 ; .115$ \\
\hline \multicolumn{6}{|l|}{ Source of information about aesthetic surgery } \\
\hline Health professionals & 83 & 28.7 & $12.60 \pm 4.35$ & $19.20 \pm 6.09$ & $31.80 \pm 9.33$ \\
\hline Internet & 78 & 27.0 & $12.80 \pm 3.79$ & $18.52 \pm 5.81$ & $31.33 \pm 8.82$ \\
\hline Friends & 54 & 18.7 & $14.07 \pm 4.38$ & $20.77 \pm 6.52$ & $34.85 \pm 10.01$ \\
\hline Media (e.g. TV, newspapers) & 50 & 17.3 & $13.86 \pm 3.60$ & $21.38 \pm 6.13$ & $35.24 \pm 8.46$ \\
\hline Family & 19 & 6.6 & $10.73 \pm 3.63$ & $18.26 \pm 7.70$ & $29.00 \pm 8.97$ \\
\hline \multirow[t]{2}{*}{ Magazines } & 5 & 1.7 & $8.40 \pm 3.13$ & $14.00 \pm 4.79$ & $22.40 \pm 6.58$ \\
\hline & $F ; p$ & & $3.915 ; .002^{\star}$ & $2.728 ; .020^{*}$ & $3.748 ; .003^{*}$ \\
\hline \multicolumn{6}{|l|}{ The reaction of social environment towards the aesthetic surgery } \\
\hline Liked it / Approved of it & 232 & 79.7 & $12.77 \pm 4.04$ & $19.19 \pm 5.97$ & $31.96 \pm 8.98$ \\
\hline Judged me/Condemned me & 41 & 14.1 & $14.26 \pm 4.75$ & $23.00 \pm 6.77$ & $37.26 \pm 10.47$ \\
\hline \multirow[t]{2}{*}{ Did not like it } & 16 & 5.5 & $12.18 \pm 3.01$ & $15.68 \pm 6.26$ & $27.87 \pm 7.14$ \\
\hline & $F ; p$ & & $2.596 ; .076$ & $10.120 ; .001^{\star \star}$ & $8.042 ; .001^{* \star}$ \\
\hline Total & & & $12.95 \pm 4.13$ & $19.53 \pm 6.30$ & $32.49 \pm 9.34$ \\
\hline
\end{tabular}

${ }^{*} p<.05{ }^{* *} p<.001$.

SPAS: Social Physique Anxiety Inventory; PAR: Physical Appearance Relaxation; NEE: Negative Evaluation Expectation; F: ANOVA.

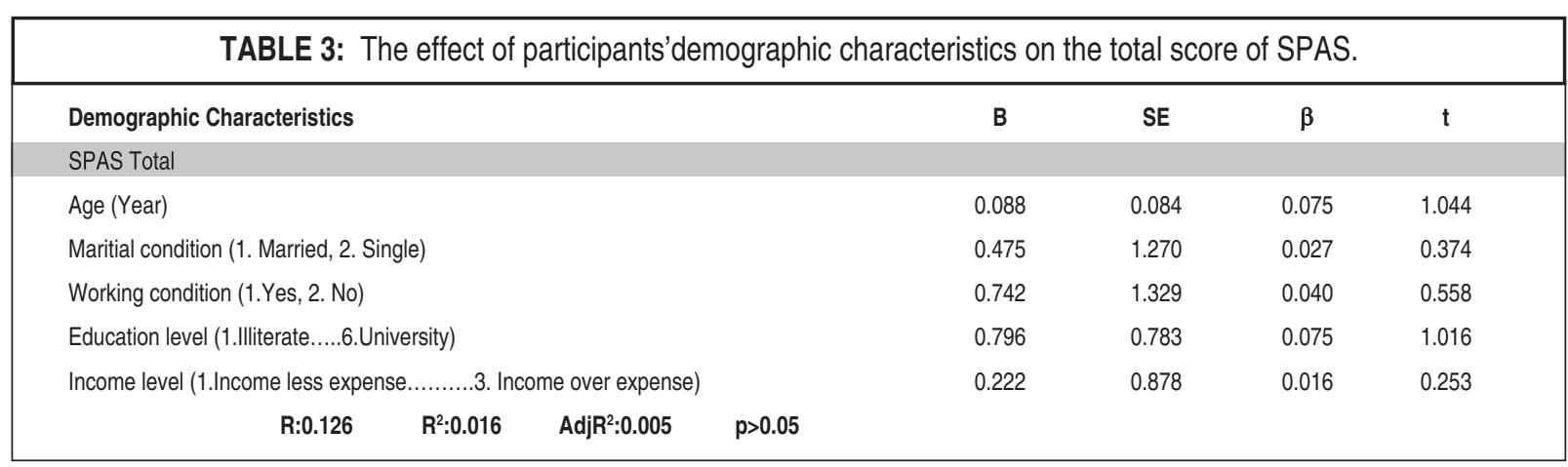

SPAS: Social Physique Anxiety Inventory B: unstandardized coefficient of regression; SE: standard error; $\beta$ : standardized coefficient of regression; $\mathrm{R}^{2}$ : coefficient of determination. 


\section{DISCUSSION}

A sense of beauty is part of cultural identity and currently there is a growing number of aesthetic surgery being conducted to make individuals feel more beautiful. ${ }^{16,18,19}$ It is indicated in the relevant literature that a temporary crisis or a problem that affects the emotional situation might cause individuals to decide to have aesthetic surgery in a short period of time, without thinking about it comprehensively. It is also stated that individuals may give up the idea of having aesthetic surgery when their current problem is solved, since it will lead to a change in their body image perception..$^{20,21}$ For this reason, it is essential that physicians evaluate how long the individuals have been dissatisfied with their physical appearance when they apply for aesthetic surgery. In this study, the average period of time participants spent considering having aesthetic surgery was $38.91 \pm 3.73$ months. The primary factors for postponing aesthetic interventions were: being afraid of having aesthetic surgery; failing to find a physician to trust; believing that own age was not suitable for such an interventions; and financial reasons. In this study, the participants considered having aesthetic surgery for long periods of time, and $88 \%$ of them said that they did not have any regrets after their interventions (Table 1).

Aesthetic surgery has a direct influence on an individual's happiness. The relevant literature shows that people feel more self-confident and energetic, and also happier after having aesthetic surgery. ${ }^{22-25}$ This paves the way for individuals to become happy and feel healthier. ${ }^{22,25}$ The study found that participants mainly had positive thoughts and feelings after having aesthetic surgery which were: being more relaxed and self-confident; more attractive and beautiful/handsome; more feminine; more successful in family social and professional relationships; and more satisfied sexually (Table 1). Rankin et al. (1998) determined that aesthetic surgery increased selfconfidence, had a positive effect on social life, made individuals more satisfied with their physical appearance, and influenced their relationships and sexual lives pos- itively. ${ }^{14}$ Yildız and Şelimen (2015) found that there was a significant increase in individuals' body image mean scores after having aesthetic surgery. ${ }^{26}$ The finding of this study is consistent with the literature.

Television is still the most effective and popular mass media instrument despite technological developments. ${ }^{27,28}$ In this study, the participants watched TV $2.39 \pm 1.59$ hours a day on average, and the most frequently watched TV programs were soap operas and movies, and entertainment programs. Markey and Markey (2010) conducted an empirical study, and determined that those who watched TV programs were more willing to have aesthetic surgery and change their physical appearances compared to those who did not watch TV programs. ${ }^{29}$ In addition, that study found that the participants who mainly learned about aesthetic surgery from the media had the highest mean scores on SPAS, which indicated the highest anxiety level $(\mathrm{p}<.05)$ (Table 2$)$.

Recently, the internet-based posts, described as "social media", have appeared to be the tools that are frequently used by individuals to learn about the subjects about which they are curious. ${ }^{27,30} \mathrm{How}^{-}$ ever, the current media commonly presents "virtual" people who have ideal smooth skins and almost perfect bodies, which is believed to affect participants' aesthetic perspective and increase their social physique anxiety levels. ${ }^{27}$ The literature describes mediz as the fourth power after the executive, the legislature and the judiciary and states that being exposed to the media was one of the factors that influenced women's approach to aesthetic surgery, which supports the argument of this study. ${ }^{7,8,27,31}$

The facial area has an important part in first impressions in the social environment. There were many interventions undergone on the facial area with the purpose of enhancing individuals' quality of life. In this study, the PAR mean score of the participants who had anti-aging operation was the highest, which indicated the highest anxiety level $(p<.05)$. In addition, the total SPAS mean score of the participants who had anti-aging operation was 
higher than the participants having had other operations $(\mathrm{p}<.05)$ (Table 2). Slevec and Tiggeman (2010) conducted a study with middle-aged women, and found that investment in physical appearance and elderly anxiety disorder were the influential factors in aesthetic surgery. ${ }^{8}$ Eriksen (2012) determined that those who underwent aesthetic surgery to look younger were more satisfied with their physical appearance and had less elderly anxiety. ${ }^{32}$ The study findings are consistent with the relevant literature.

Individuals are willing to look beautiful in accordance with the beauty norms of the society they live in. ${ }^{33}$ When people think that they do not make a good first impression on others, they feel anxiety and try to make themselves look more beautiful through aesthetic surgery. ${ }^{4}$ The study found that the individuals who decided to have aesthetic surgery because of the negative evaluations they got from others had high NEE mean scores $(\mathrm{p}<.05)$ (Table 2). The studies conducted with different samples in the relevant literature revealed that judgmental thoughts and beliefs about the body appearance, as well as the fear of being teased, decreased bodily satisfaction and increased interest in aesthetic surgery. ${ }^{8,12,15,23,31}$ Moreover, it was found that the perspective of society, self-esteem and body perception were very important in individuals' decisions to have aesthetic surgery. ${ }^{34,35}$ The finding of this study are consistent with the relevant literature. The influence of traditional Turkish family structure, marital relationships and religious and economic factors on the aesthetic surgery decision would stimulate social reaction to aesthetic surgery. A supportive finding of the study was that the participants who were judged or condemned by those in their social environment because of the aesthetic surgery they had the highest mean scores on PAR and NEE sub-dimensions, as well as the entire SPAS scale, which indicated that they had the highest anxiety levels (Table 2). Mirijello et al. (2015) determined that the individuals who had obesity surgery for aesthetic purposes had high levels of social phobia before having surgery. ${ }^{36}$ Fındıkçıŏlu et al. (2005) stated that individuals from different nations and with different sociocul- tural characteristics perceived the aesthetic surgery and their results in different ways. In Turkey, in particular, individuals having aesthetic surgery for aesthetic problems, or for reconstructive reasons, were different from each other in sociocultural terms. ${ }^{34}$ The finding of this study is in line with the relevant literature (Table 2).

In the study determined that the variables of age, marital status, employment status, education level and income level did not affect the total score of SPAS ( $p>$.05) (Table 3). Similarly, Ayaz determined that education level, employment status and economic status did not affect body perception. 30 The finding of this study is consistent with the finding of Ayaz.

In addition, women not only have social physique anxiety about their physical appearance, they also have concerns about their genital organs appearance. In this direction, the rates of genital aesthetic surgery have increased in the Worldwide and in our country in recent years. Genital aesthetic surgery including labiaplasty, vaginoplasty, clitoral hoodectomy, clitoral repositioning, clitoral repositioning, g-spot amplification, perineoplasty, hymenoplasty operations have been frequently heard in recent years, especially with labiaplasty and vaginoplasty. ${ }^{37}$ According to International Society of Aesthetic Plastic Surgery (ISAPS) stated that 56,169 labiaplasty and 50,086 vaginoplasty operations were performed worldwide in 2016. These operations have increased by $0.5 \%$ and $0.6 \%$, respectively, when compared to the previous year. ${ }^{6}$

\section{CONCLUSION}

To conclude, the study found that the participants waited for a long period of time before having a aesthetic surgery, they were mainly influenced by their social environment and media, and the individuals who received negative feedback from their social environment had a greater social physique anxiety. For this reason, there is need for more reliable sources of information about aesthetic surgery, and social training programs provided by the mass media would change the perspective of soci- 
ety towards aesthetic surgery in a conscious way. In order to better understand the factors affecting the level of social physique anxiety; it may be advisable to study in larger sample groups in which variables such as different age groups, gender, body perception levels, body image satisfaction and BMI are addressed.

\section{Human Subject Statement}

The researchers obtained the approval of the Dicle University Medical Faculty Non-invasive Clinical Research Board (Approval \# 2013/13) before conducting the study.

\section{Acknowledgements}

We would like to thank the women who participated and completed this questionnaire.

\section{Conflict of Interest}

Authors declared no conflict of interest or financial support.

\section{Authorship Contributions}

Idea/Concept: Yeşim Aksoy Derya, Sermin Timur Taşhan, Mesude Duman, Gülçin Nacar; Design: Yeşim Aksoy Derya, Sermin Timur Taşhan; Control/Supervision: Yeşim Aksoy Derya, Sermin Timur Taşhan; Data Collection and/or Processing: Yeşim Aksoy Derya, Sermin Timur Taşhan, Mesude Duman, Gülçin Nacar; Analysis and/or Interpretation: Yeşim Aksoy Derya, Sermin Timur Taşhan; Literature Review: Yeşim Aksoy Derya, Sermin Timur Taşhan, Mesude Duman, Gülçin Nacar; Writing the Article: Yeşim Aksoy Derya, Sermin Timur Taşhan, Mesude Duman, Gülçin Nacar; Critical Review: Yeşim Aksoy Derya, Sermin Timur Taşhan, Mesude Duman, Gülçin Nacar; References and Fundings: Yeşim Aksoy Derya, Sermin Timur Taşhan, Mesude Duman, Gülçin Nacar.

\section{REFERENCES}

1. Yaman Ç, Teşneli Ö, Koşu S, Yalvarıcı N, Tel $\mathrm{M}$, Gelen N. [The effects of different kinds of elite sport branches on physical self-perception]. International Journal of Human Sciences 2005;5(2):1-17.

2. Hart EA, Leary MR, Rejeski WJ. The measurement of social physique anxiety. J Sport Exerc Psychol 1989;11:94-04.

3. Khazir Z, Dehdari T, Majdabad MM, Tehrani SP. Psychological aspects of cosmetic surgery among females: a media literacy training intervention. Glob J Health Sci 2016;8(2):3545.

4. Cooper LB. Nursing students' perceptions of clients undergoing elective cosmetic surgery. Plast Surg Nurs 2007;27(3):15862.

5. American Society of Plastic Surgeons (ASPS). Cosmetic Plastic Surgery Statistics Report. US: ASPS; 2016. p.23.

6. ISAPS International Survey on Aesthetic/Cosmetic Procedures Performed in 2016. Columbus: ISAPS; 2016. p.105.

7. Ashikali EM, Dittmar $\mathrm{H}$, Ayers $\mathrm{S}$. The impact of cosmetic surgery advertising on women's body image and attitudes towards cosmetic surgery. Psychol Pop Media Cult 2017;6(3): 255-73.

8. Slevec J, Tiggeman M. Attitudes toward cosmetic surgery in middle-aged women: body image, aging anxiety, and the media. Psychol Women Q 2010;34(1):65-4.

9. Haas CF, Champion A, Secor D. Motivating factors for seeking cosmetic surgery: a syn- thesis of the literature. Plast Surg Nurs 2008;28(4):177-82.

10. Jonzon K. Cosmetic medical treatments: why are we so obsessed with beauty-is it nature or nurture? Plast Surg Nurs 2009;29(4):222-5.

11. Mohammadi MN, Assadollahi E, Niazifar M. Social physique anxiety and its relation with body dysmorphic disorder. EJSBS 2015;13(2):1736-46.

12. von Soest T, Kvalem IL, Skolleborg KC, Roald $\mathrm{HE}$. Psychosocial factors predicting the motivation to undergo cosmetic surgery. Plast Reconstr Surg 2006;117(1):51-62.

13. von Soest T, Kvalem IL, Wichstrøm L. Predictors of cosmetic surgery and its effects on psychological factors and mental health: a population-based follow-up study among Norwegian females. Psychol Med 2012;42(3): 617-26.

14. Rankin M, Borah GL, Perry AW, Wey PD. Quality-of-life outcomes after cosmetic surgery. Plast Reconstr Surg 1998;102(6):2139-45.

15. Javo IM, Sørlie T. Psychosocial characteristics of young Norwegian women interested in liposuction, breast augmentation, rhinoplasty, and abdominoplasty: a population-based study. Plast Reconstr Surg 2010;125(5):153643.

16. Sarwer DB, Crerand CE. Body image and cosmetic medical treatments. Body Image 2004;1(1):99-111.

17. Ballı ÖM, Aşçı FH. [Reliability and validity of "social physique anxiety scale"]. Hacettepe J of Sport Sciences 2006;17(1):11-9.
18. Crerand CE, Franklin ME, Sarwer DB. Body dysmorphic disorder and cosmetic surgery. Plast Reconstr Surg 2006;118(7):167e-80e.

19. Javanbakth $M$, Nazari $A$, Javanbakth $A$, Moghaddam L. Body dysmorphic factors and mental health problems in people seeking rhinoplastic surgery. Acta Otorhinolaryngol Ital 2012;32(1):37-40.

20. Küçükkaya $P G$. [The role of the nurse in the pre-op psychosocial assessment in cosmetic surgery]. J Psy Nurs 2011;2(2):94-9.

21. Malick F, Howard J, Koo J. Understanding the psychology of the cosmetic patients. Dermatol Ther 2008;21(1):47-53.

22. Cochran CS, Marin VP. A systematic approach to open rhinoplasty. Oper Tech Otolaryngol Head Neck Surg 2007;18(3):166-71.

23. Cook SA, Rosser R, Toone H, James MI, Salmon P. The psychological and social characteristics of patients referred for NHS cosmetic surgery: quantifying clinical need. $J$ Plast Reconstr Aesthet Surg 2006;59(1):5464.

24. Crerand CE, Infield AL, Sarwer DB. Psychological considerations in cosmetic breast augmentation. Plast Surg Nurs 2009;29(1):49-57.

25. Honigman RJ, Phillips KA, Castle DJ. A review of psychosocial outcomes for patients seeking cosmetic surgery. Plast Reconstr Surg 2004;113(4):1229-37.

26. Yıldız T, Selimen D. The impact of facial aesthetic and reconstructive surgeries on patients' quality of life. Indian J Surg 2015;77(Suppl 3):831-6. 
27. Aktaş S. [Influences of media on women's aesthetics and the role of midwife]. Journal of Anatolia Nursing and Health Sciences 2014;17(3):187-95.

28. Wegenstein B, Ruck N. Physiognomy, reality TV, and the cosmetic gaze. Body Soc 2011;17(4):27-54.

29. Markey CN, Markey PM. A correlational and experimental examination of reality television viewing and interest in cosmetic surgery. Body Image 2010;7(2):165-71.

30. Ayaz S. Body image in the patients having aesthetic and reconstructive surgery. Turk Med J 2008;2(1):24-9.
31. Sharp G, Tiggemann M, Mattiske J. The role of media and peer influences in Australian women's attitudes towards cosmetic surgery. Body Image 2014;11(4):482-7.

32. Eriksen SJ. To cut or not to cut: cosmetic surgery usage and women's age-related experiences. Int J Aging Hum Dev 2012;74(1): 1-24.

33. Kök AN, Çankaya H. [Medical, ethic and legal problems in esthetic aimed medical interventions]. Turkiye Klinikleri $\mathrm{J}$ Med Ethics 2003;11(3):199-203

34. Fındıkçıoğlu K, Fındıkçıoğlu F, Özmen S, Çelebi MC. [Profile of aesthetic and recon- structive patients hospitalized in our department]. Gazi Med J 2005;16(2):70-3.

35. von Soest T, Kvalem IL, Roald HE, Skolleborg $\mathrm{KC}$. The effects of cosmetic surgery on body image, self-esteem, and psychological problems. J Plast Reconstr Aesthet Surg 2009;62(10):1238-44.

36. Mirijello A, D'Angelo C, laconelli A, Capristo E, Ferrulli A, Leccesi L, et al. Social phobia and quality of life in morbidly obese patients before and after bariatric surgery. J Affect Disord 2015;179:95-100.

37. Beşen MA. [Sexuality and aesthetic]. Duzce Medical Journal 2014;16(1):70-2. 